\title{
THE ROLE OF "PAGUYUBAN REMAJA PEDULI HIV/AIDS SIDOARJO" (PARPAS) ON KNOWLEDGE, ATTITUDE, AND ACTION FOR HIV/AIDS PREVENTION IN SENIOR HIGH SCHOOLS IN SIDOARJO
}

\author{
Adelia Dwi Pratiwi', Windhu Purnomo \\ ${ }^{1,2}$ Department of Biostatistics and Population, Faculty of Public Health, Universitas Airlangga, 60115 Surabaya, East Java, \\ Indonesia \\ Corresponding Author: Adelia Dwi Pratiwi \\ E-mail: adeliadwipratiwi97@gmail.com
}

\begin{abstract}
There were total of 2,100,000 new HIV infections worldwide and 1,500,000 deaths from AIDS recorded in 2013. The total HIV/AIDS cases in 2017 in Sidoarjo reached 476 cases and cumulatively reached 1,245 cases. HIV/AIDS is a well-known topic among teenagers. Teenagers are often associated with physical development in puberty phase which usually followed by sexual development. Furthermore, they also experience changes emotionally and physically which are projected in their behavior and attitude. These circumstances make teenagers prone to the risky behavior towards HIV/AIDS transmission. This study aims to analyze the role of "Paguyuban Peduli HIV/AIDS Sidoarjo" or PARPAS on teenagers' knowledge, attitude, and behavior towards HIV/AIDS prevention. This research is an observational analytic using cross-sectional research design. The population of the study is all students of SMAN 1 Taman and SMAN 1 Sidoarjo, 2,370 students in total. The sampling technique uses simple random sampling and the sample size is 100 students. The result shows that there is correlation between PARPAS role on knowledge and attitude of students' in Sidoarjo towards HIV/AIDS prevention. Nevertheless, there is no correlation between PARPAS role on students' behavior towards HIV/AIDS prevention. Suggestions concluded from the results are including early detection, attempt in joining organization related to HIV/AIDS awareness, and health education given to both students and parents.
\end{abstract}

Keywords: Action, HIV/AIDS, Paguyuban Remaja Peduli HIV/AIDS Sidoarjo (PARPAS), Teenagers

\section{ABSTRAK}

Tercatat pada tahun 2013 di seluruh dunia terdapat 2.100.000 infeksi baru HIV dan jumlah kematian akibat AIDS ebanyak 1.500.000 jiwa. Jumlah kasus HIV/AIDS tahun 2017 di Sidoarjo mencapai 476 kasus dan jumlah kumulatif HIV/AIDS di Sidoarjo mencapai 1.245 kasus. Kasus HIV/AIDS kini telah popular juga dikalangan remaja. Remaja pada masanya erat berkaitan dengan perkembangan psikis di masa pubertas serta dibarengi dengan perkembangan seksual. Para remaja juga melalui perubahan yakni perubahan emosional dan fisik kemudian tergambar pada tindakan dan sikap. Kondisi tersebut menjadikan remaja lebih rentan pada kasus perilaku berisiko terhadap penularan HIV/ AIDS. Tujuan penelitian yakni menganalisis peran paguyuban peduli HIV/AIDS Sidoarjo terhadap pengetahuan, sikap dan tindakan remaja terhadap pencegahan penularan HIV/AIDS. Jenis penelitian yaitu analitik observasional dengan cross sectional sebagai desain penelitian. Populasi penelitian yakni seluruh siswa yang tercatat sebagai siswa-siswi di SMA Negeri 1 Taman dan SMA Negeri 1 Sidoarjo yang berjumlah 2.370. Teknik pengambilan sampel yakni simple random sampling dan besar sampel yaitu 100 siswa. Hasil penelitian menunjukkan adanya korelasi antara peran PARPAS terhadap pengetahuan dan sikap siswa SMA di Sidoarjo tentang pencegahan HIV/AIDS. Namun, tidak terdapat korelasi antara peran PARPAS terhadap perilaku siswa SMA di Sidoarjo tentang pencegahan HIV/AIDS. Saran dari hasil penelitian yaitu melakukan deteksi dini, mengikuti organisasi, dan penyuluhan kesehatan kepada siswa dan orang tua.

Kata kunci: HIV/AIDS, Paguyuban Remaja Peduli HIV/AIDS Sidoarjo (PARPAS), Remaja, Tidakan

\section{INTRODUCTION}

HIV (Human Immunodeficiency Virus) is a type of virus that will infect leukocytes, causing decreased immunity. Furthermore, AIDS (Acquired Immune Deficiency Syndrome) is a disease arises from the low immunity of an individual's body due to HIV 
infection. Risk factors for HIV/AIDS including drugs injections, homosexual intercourse are commonly known as MSM (men have sex with men), heterosexual intercourse, etc (Indonesian Ministry of Health, 2014).

In Indonesia cases of HIV/AIDS began to rise in number. Recorded in 2013 , there were 2,100,000 new HIV infections around the world divided into 1,900,000 adults and 240,000,000 children under 15 years old. The total mortality due to AIDS is 1.5 million people. The first case of HIV/AIDS in Indonesia was found in 1987 and the total number of AIDS cases until March 2011 was $10.62 \%$ per 100 thousand population. The cumulative number of AIDS cases in 2014 in East Java was 19,249, placing it on the second rank just after DKI Jakarta (Indonesian Ministry of Health, 2014).

HIV/AIDS cases are well-known among teenagers nowadays as a result of globalization era. The growing number of informational media allows teenagers to access all kinds of information without any restrictions. Therefore, globalization era has led to the emergence of social changes and the current lifestyle of adolescents, especially in urban areas. In addition to the increasingly lively contemporary lifestyle, unlimited access to information related to sexual activities is also available for teenagers. The information they have obtained triggers curious teenagers to commit deviant behavior. According to Kusuma (2010), adolescents in urban areas more likely to show risky behaviors such as exchange sexual partners, drug abuse, and sex before marriage. This lifestyle can endanger reproductive health, especially allowing the transmission of HIV/AIDS or other sexually transmitted diseases to other people.

The number of HIV/AIDS cases in 2017 in Sidoarjo reached 476 cases and the cumulative number of HIV/AIDS in Sidoarjo reached 1,245 cases. Increased sexual activity in adolescents makes teens tend to try to find more information related to sex. Thus, one important element in HIV prevention is focused on adolescents as well as young adult groups. Adolescent groups, including vulnerable groups in STIs and the most total, suffer from HIV/AIDS. A teenager in his time is closely related to the development of psychology at puberty and also accompanied by sexual development. The teenagers are immediately through a change that is emotional and physical changes later on later in the behavior (actions) and attitudes. These conditions make adolescents more vulnerable in cases of risky behavior against HIV/AIDS transmission.

Sidoarjo has a youth organization that is known as Paguyuban Remaja Peduli HIV/AIDS (PARPAS). PARPAS is an organization under the auspices of the Department of Youth, Sports, and Tourism and the Child Protection Commission which focuses on education and counselling for young adults. The members of the organization consist of young adults in order to make the education process easier. One of PARPAS's activities is providing education and counselling related to HIV/AIDS in schools. PARPAS hopes to have a positive impact on adolescents regarding HIV/AIDS in Sidoarjo.

This is supported by research Susanti (2015) which concluded that counselling had a significant influence on teenagers' knowledge related to reproductive health. Similarly, it also affects teenagers' knowledge about sexually transmitted diseases or HIV/AIDS. Counselling will be able to increase individual self-capacity, insights gained from counselling are not necessarily obtained in school. Therefore, having counselling will help complement individual insights beyond what is delivered at school. Thus, this research is carried out to examine exposure to education to the schools that have been visited or have never been visited by PARPAS towards teenagers' attitudes related to sexual activities before marriage that focuses on HIV/AIDS transmission, knowledge about HIV/AIDS as well as behavior to the prevention of HIV/AIDS transmission during adolescent phase.

\section{METHODS}

The research is observational analytic with a quantitative research design. This research is more focused on the measurement of variables at a certain time and simultaneously or commonly called cross-sectional taking techniques. Research settings are in SMAN 1 Taman and SMAN 1 Sidoarjo. The study was conducted from March to June 2019.

The study population are all students of SMAN 1 Taman and SMAN 1 Sidoarjo, as many as 2,370 students. The sample of the research are several students from SMAN 1 Taman and SMAN 1 Siodarjo. Research inclusion criteria are students who attend school and are willing to become research respondents. The way to take a sample is simple random 
sampling by draw. After calculated using the Lemeshow formula the size of the study sample is 100 students.

The role of PARPAS is an independent variable of research. While knowledge, attitudes, and HIV/AIDS prevention measures are the dependent variable of the study. All data was taken using a questionnaire. Then the data are analyzed univariately and bivariate analysis through statistical tests.

This research has undergone a series of ethical tests. Ethics testing is carried out to assure that this research does not violate ethics when data is collected so that neither respondents nor researchers will feel disadvantaged. This study passed an ethical test conducted by the Universitas Airlangga Faculty of Dentistry ethics commission. Then issued a certificate of ethics under number 504/HRECC.FODM/VII/2019.

\section{RESULT}

\section{General Description of SMAN 1 Taman and SMAN 1 Sidoarjo}

Senior High School is an advanced level taken after completing the Primary High School level. Sidoarjo Regency has 70 Senior High Schools divided into 13 Public Schools and 57 Private Schools (Ministry of Education and Culture, 2019). In this research, SMAN 1 Taman and SMAN 1 Sidoarjo have been selected as research locations. The following is an overview of SMAN 1 Taman and SMAN 1 Sidoarjo.

\section{Description of SMAN 1 Taman}

SMAN 1 Taman was established in 1984 following the Ministry of Education and Culture Decree No. 0558/0/1984. It was located in SMAN 1 Taman building located at Jl. Satria 1 Ketegan, Taman until November $19^{\text {th }}, 1986$ before moved to the new building in $\mathrm{Jl}$. Sawunggaling 2 Jemundo, Taman on November $20^{\text {th }}, 1986$ until today. SMAN 1 Taman is under the supervision of Mr. Pranoyo as the headmaster with 58 teachers, 432 male students, 686 female students, and 33 study groups.

The area of the Taman 1 Senior High School is $8000 \mathrm{~m}^{2}$ with 33 classrooms/study groups, one headmaster's room, one counselling guidance room, one vice principal's room, and five laboratories namely Language Lab,
Biology Lab, Physics Lab, Technology Lab, Chemistry Lab, one Administration room, one Library room, one mosque named Baitul Ilmi with 50 water taps for washing hands and wudhu, two teachers/staffs bathrooms, 12 classrooms, one room for the principal and other supporting facilities.

SMAN 1 Taman has visions which aims for excellence in achievement, noble characters, high work ethic, and global outlook based on the nation's culture. Whereas the mission including (1) To increase piety and faith in God; (2) Fostering an orderly and disciplined attitude, a high work ethic towards all school residents (3) Improving the quality of learning services according to the program, and also improving student learning achievement and work performance.

\section{Description of SMAN 1 Sidoarjo}

SMAN 1 Sidoarjo was established on August 1989 based on the Ministry of Education and Culture Republic of Indonesia Decree No: 0371/0/1978. SMAN 1 Sidoarjo is supervised under Mrs. Ristiwi Peni as the school principal with total of 65 teachers, 532 male students, 719 female students, and 39 study groups.

SMAN 1 Sidoarjo is located at Jl. Jenggolo No.1 Pucang, Sidoarjo. The school has an area of $18,192 \mathrm{~m}^{2}$ with 38 classrooms/study groups, one headmaster's room, one Counselling Guidance room, one vice principal's room, and five laboratories namely Biology Lab, Physics Lab, Information Technology Lab, Chemistry Lab, Language Lab, one Administration room, one Library room, and other supporting facilities.

SMAN 1 Sidoarjo aims to be Superior in Science, Technology, Peace Culture, and Imtaq. SMAN 1 Sidoarjo also sets some objectives including (1) Developing religious behavior around the school so that a culture of wisdom is formed when acting; (2) Carrying out merger of character education in all subjects continuously and intact so as to create a social ethic with a culture of high discipline and courtesy; (3) Improving the quality of education based on the School Curriculum oriented to life skills based on the demands of the community and the development of science and technology so that school residents are able to compete in the global era; (4) Implementing teaching and learning processes based on the School Curriculum so that educators and students are 
also able to create conditions for learning that are creative, active, effective, enlightening, and enjoyable; (5) Producing school graduates who have life skills, motivation, commitment, creativity for leadership, independent social sensitivity, and; (6) Developing the interest of the academic community to realize creativity and renewal in the field of education; (7) Carrying out participatory management in all fields, mainly in decision making in an effort to improve SBQIM (School Based Quality Improvement Management).

\section{Description of Perception of the Role of PARPAS}

Perception of the role of the PARPAS is analyzed through exposure to education towards the schools that have been attended or never visited by PARPAS. The following is the frequency distribution of respondents' perceptions about the role of PARPAS.

Table 1. Frequency Distribution of Respondents' Perceptions about the Role of PARPAS

\begin{tabular}{lcc}
\hline \multirow{2}{*}{ The role of PARPAS } & \multicolumn{2}{c}{ Amount } \\
\cline { 2 - 3 } & $\mathbf{n}$ & $\boldsymbol{\%}$ \\
\hline Yes & 50 & 50.0 \\
No & 50 & 50.0 \\
\hline Total & 100 & 100 \\
\hline
\end{tabular}

According to Table 1, it can be concluded that the respondents who felt the role of the PARPAS were 50 respondents (50.0\%). Whereas respondents who did not feel the role of PARPAS were 50 respondents (50.0\%). Obtained a balanced comparison between respondents who did not feel the role and respondents felt the role of PARPAS.

\section{Overview of Knowledge on HIV/AIDS Prevention}

Knowledge is all things that individuals know about HIV/AIDS prevention not only in schools (formal) but can also be learned in the society (non-formal). According to Table 2., it can be seen that 56 subjects $(56.0 \%)$ are wellinformed about HIV/AIDS prevention. Whereas subjects who were not knowledgeable about HIV/AIDS prevention were 44 subjects $(44.0 \%)$. The majority of subjects have good knowledge related to HIV/AIDS prevention.
Table 2. Frequency Distribution of HIV/AIDS Prevention Knowledge

\begin{tabular}{lcc}
\hline \multirow{2}{*}{ Knowledge } & \multicolumn{2}{c}{ Amount } \\
\cline { 2 - 3 } & n & \% \\
\hline Good & 56 & 56.0 \\
Not good & 44 & 44.0 \\
\hline Total & 100 & 100 \\
\hline
\end{tabular}

\section{Overview of HIV/AIDS Prevention Attitudes}

The attitude which is one form of continued response by individuals after having knowledge related to HIV/AIDS prevention, the formation of attitudes is indirectly influenced by the level of individual knowledge. The following is a frequency distribution of attitudes related to HIV/AIDS prevention.

Table 3. Frequency Distribution of HIV/AIDS Prevention Attitudes

\begin{tabular}{lcc}
\hline \multirow{2}{*}{ Attitude } & \multicolumn{2}{c}{ Amount } \\
\cline { 2 - 3 } & n & \% \\
\hline Good & 56 & 56.0 \\
Not good & 44 & 44.0 \\
\hline Total & 100 & 100 \\
\hline
\end{tabular}

According to Table 3., as many as 56 respondents $(56.0 \%)$ showed positive behavior towards HIV/AIDS prevention. While respondents who behaved poorly towards HIV/AIDS prevention were 44 respondents $(44.0 \%)$. The majority of respondents have positive behavior concerning HIV/AIDS prevention.

\section{Overview of HIV/AIDS Prevention Measures}

The action is a realization of activities as a result of prior knowledge and attitudes. The following is a frequency distribution of actions related to HIV/AIDS prevention.

Table 4. Frequency Distribution of HIV/AIDS Prevention Measures

\begin{tabular}{lcc}
\hline \multirow{2}{*}{ Action } & \multicolumn{2}{c}{ Amount } \\
\cline { 2 - 3 } & $\mathbf{n}$ & $\boldsymbol{\%}$ \\
\hline Good & 49 & 49.0 \\
Not good & 51 & 51.0 \\
\hline Total & 100 & 100 \\
\hline
\end{tabular}

According to Table 4. it can be viewed that the respondents who have good actions related 
to HIV/AIDS prevention are 49 respondents $(49.0 \%)$. While 51 respondents $(51.0 \%)$ did not have good actions related to HIV/AIDS prevention. The majority of respondents have had bad actions related to HIV/AIDS prevention.

The Relationship of the Role of PARPAS towards the Knowledge on HIV/AIDS Prevention

Based on Table 5., respondents who are well-informed and feel the role of the PARPAS are 34 respondents $(34.0 \%)$. Respondents who were well-informed and did not feel the role of PARPAS were 22 respondents (22.0\%). Respondents who were not well informed and felt the role of the PARPAS were 16 respondents $(16.0 \%)$. Also, respondents who were not well informed and did not feel the role of PARPAS were 28 respondents $(28.0 \%)$.

Following the statistical test, a large pvalue of 0.027 was obtained ( $\mathrm{p}$-value $<0.05$ ).
This means that there is a correlation between the role of PARPAS with HIV/AIDS prevention knowledge in high school students in Sidoarjo.

\section{Relationship between PARPAS and HIV/AIDS Prevention Attitudes}

According to Table 6., respondents who behave well and feel the role of the PARPAS are 34 respondents (34.0\%). Respondents who behaved well and did not feel the role of PARPAS were 22 respondents (22.0\%). Respondents who behaved badly and felt the role of PARPAS were 16 respondents (16.0\%). 28 respondents $(28.0 \%)$ behaved poorly and did not feel the role of PARPAS.

Following the statistical test, a large pvalue of 0.027 was obtained ( $p$-value <0.05). This means that there is a correlation between the role of PARPAS with HIV/AIDS prevention knowledge in high school students in Sidoarjo.

Table 5. The Relationship of the Role of PARPAS towards Knowledge on HIV/AIDS Prevention

\begin{tabular}{|c|c|c|c|c|c|c|}
\hline \multirow{3}{*}{$\begin{array}{c}\text { The role of } \\
\text { PARPAS }\end{array}$} & \multicolumn{4}{|c|}{ Knowledge } & \multirow{2}{*}{\multicolumn{2}{|c|}{ Total }} \\
\hline & \multicolumn{2}{|c|}{ Good } & \multicolumn{2}{|c|}{ Less } & & \\
\hline & $\mathrm{n}$ & $\%$ & $\mathrm{n}$ & $\%$ & $\mathrm{n}$ & $\%$ \\
\hline Yes & 34 & 34.0 & 16 & 16.0 & 50 & 50 \\
\hline No & 22 & 22.0 & 28 & 28.0 & 50 & 50 \\
\hline Total & 56 & 56.0 & 44 & 44.0 & 100 & 100 \\
\hline & & & $=0$ & & & \\
\hline
\end{tabular}

Table 6. Relationship between PARPAS and HIV/AIDS Prevention Attitudes

\begin{tabular}{|c|c|c|c|c|c|c|}
\hline \multirow{3}{*}{$\begin{array}{c}\text { The role of } \\
\text { PARPAS }\end{array}$} & \multicolumn{4}{|c|}{ Attitude } & \multirow{2}{*}{\multicolumn{2}{|c|}{ Total }} \\
\hline & \multicolumn{2}{|c|}{ Good } & \multicolumn{2}{|c|}{ Less } & & \\
\hline & $\mathbf{n}$ & $\%$ & n & $\%$ & $\mathrm{n}$ & $\%$ \\
\hline Yes & 34 & 34.0 & 16 & 16.0 & 50 & 50 \\
\hline No & 22 & 22.0 & 28 & 28.0 & 50 & 50 \\
\hline Total & 56 & 56.0 & 44 & 44.0 & 100 & 100 \\
\hline & & $p-1$ & .027 & & & \\
\hline
\end{tabular}

Table 7. The Relationship of PARPAS HIV/AIDS Prevention Action

\begin{tabular}{|c|c|c|c|c|c|c|}
\hline \multirow{3}{*}{$\begin{array}{c}\text { The role of } \\
\text { PARPAS }\end{array}$} & \multicolumn{4}{|c|}{ Action } & \multirow{2}{*}{\multicolumn{2}{|c|}{ Total }} \\
\hline & \multicolumn{2}{|c|}{ Good } & \multicolumn{2}{|c|}{ Less } & & \\
\hline & $\mathbf{n}$ & $\%$ & $\mathbf{n}$ & $\%$ & $\mathbf{n}$ & $\%$ \\
\hline Yes & 29 & 29.0 & 21 & 21.0 & 50 & 50 \\
\hline No & 20 & 20.0 & 30 & 30.0 & 50 & 50 \\
\hline Total & 49 & 49.0 & 51 & 51.0 & 100 & 100 \\
\hline
\end{tabular}




\section{The Relationship of the Role of Youth Association Caring for HIV/AIDS Sidoarjo against HIV/AIDS Prevention}

Following Table 7., it can be learned that respondents who have good actions and feel the role of PARPAS are 29 respondents (29.0\%). Respondents who had good actions and did not feel the role of PARPAS were 20 respondents (20.0\%). 21 respondents $(21.0 \%)$ had bad actions and felt the role of PARPAS. 30 respondents $(30.0 \%)$ did not feel good and did not feel the role of PARPAS.

Following the statistical test, a p-value of 0.110 ( $\mathrm{p}$-value $>0.05$ ) is obtained, meaning that there is no correlation between the role of PARPAS and HIV/AIDS prevention measures for high school students in Sidoarjo.

\section{DISCUSSION}

\section{The Relationship between the Role of PARPAS and Knowledge of HIV/AIDS Prevention}

There is a correlation between the role of PARPAS with the knowledge of high school students in Sidoarjo. This indicates that the role of PARPAS in the form of providing information and health education is a factor that supports respondents in respondent's knowledge about HIV/AIDS.

This result is supported by research Husaini, Panghiyangani, and Saputra (2017) stated that counselling about HIV/AIDS affected the knowledge of Banjarbaru Midwifery Academy students around 4,206 times more risky. The total number of female students with good levels of knowledge increased after receiving counselling, starting from $35 \%$, increasing by $70 \%$. This result is supported by research conducted by Ayuningsih, Rondonuwu and Mulyadi (2014) where significant differences occurred in respondents during pre and post counselling, which for good knowledge pre counselling was $7(13.0 \%)$ there was a significant increase in post counselling to $41(75.9 \%)$. These results are in line with research by Widarma, Hayati, and Maidartati (2017) which stated that there is an influence of health education with counselling related to adolescent knowledge about HIV/AIDS in SMA PGRI 51 Rancakaek. This result is also supported by Worinsi (2017) that the difference before and after treatment shows the influence of counselling given to the level of HIV/AIDS preventive knowledge in adolescents at SMA Ma'arif Yogyakarta (pvalue $=0,000$ ).

According to Notoatmodjo (2010), behavior that is not based on knowledge will quickly change when compared to behavior based on individual knowledge. Knowledge about HIV/AIDS including all the things teenagers know about HIV/AIDS. PARPAS role in providing education through counselling about HIV/AIDS. Counselling from peers makes it easier for adolescents to capture the message conveyed. Adolescents who lack knowledge related to HIV/AIDS will have inappropriate behavior regarding HIV/AIDS prevention but adolescents who have received knowledge related to HIV/AIDS have a more positive outlook on life and high selfconfidence and are more optimistic to carry out preventive actions related to HIV/AIDS.

\section{The Relationship between the Role of PARPAS and HIV/AIDS Prevention Attitudes}

There is a correlation between the role of youth groups concerned with HIV/AIDS (PARPAS) with the attitudes of high school students in Sidoarjo. This indicates that the role of PARPAS in the form of providing information and health education is a factor that supports respondents in a positive attitude related to HIV/AIDS prevention.

This result is confirmed by research Natalia, Sunanrti, and Astuti (2014) resulted in a $\mathrm{p}$-value $=0.01$ meaning that there was an influence between counselling related to HIV/AIDS on the attitudes of adolescents to PLWHA at SMA 8 Yogyakarta. This result is supported by research conducted by Husaini, Panghiyangani, and Saputra, 2017) which stated that delivery of counselling related to HIV/AIDS could affect the attitudes of female students around 4,206 $\mathrm{x}$ riskier. The total number of female students who behaved improved after given counselling, ranging from $87.5 \%$ to $100 \%$. This result is also supported by Ayuningsih, Rondonuwu, and Mulyadi (2014) that is, there is an influence of counselling on students' attitudes towards HIV/AIDS. There are differences in attitude before and after counselling.

Attitude is the readiness to react to objects in the environment as a form of response to the stimulus. Counseling and education provided by PARPAS have increased student knowledge 
so that it can indirectly affect students' attitudes to respond to HIV/AIDS prevention.

\section{The Relationship between the Role of PARPAS and HIV/AIDS Prevention}

There is no correlation between the role of PARPAS and HIV/AIDS preventive measures for high school students in Sidoarjo. This indicates that the role of PARPAS in the form of providing information and health education is a factor that supports respondents' knowledge and attitudes but does not necessarily support the respondent's behavior on HIV/AIDS prevention.

This result does not support research conducted by Hamdi, Wijaya, and Iskandar (2016) where an increase in prevention behavior is higher in the group intervened by IEC ABAT in multiple sessions. KIE ABAT is an educational activity given to respondents related to HIV/AIDS prevention. This result also does not support research by Isni (2016), there is a significant correlation of support from health personnel to the behavior of mothers with HIV positive related to HIV/AIDS preventive activities transmitted by mothers to infants (pvalue $=0.010)$ and the odds ratio is 17 . These results do not support research conducted by Yuliza, Hardisman, and Nursal (2019) where there is a correlation related to staffs' support for HIV/AIDS prevention behavior ( $p=0.013$ ). This result is also not supported by Nita and Hari (2016), which is the influence between knowledge of premarital free sex behavior in vocational teenagers in Surabaya. Health worker support in the form of motivation and health education provided to respondents related to HIV/AIDS prevention

Good knowledge and attitudes do not guarantee good individual actions in HIV/AIDS prevention, therefore the role of PARPAS here only affects students' knowledge and attitudes. That is because the actions taken by students can be influenced not only by counselling from PARPAS but also by motivation from students themselves, family, and peers.

\section{CONCLUSIONS AND SUGGESTIONS}

\section{Conclusion}

According to the results of this study, it can be concluded that high school students in Sidoarjo have high knowledge and attitudes related to HIV/AIDS prevention. However, high school students in Sidoarjo do not possess behavior related to HIV/AIDS prevention. After analysis, it was found that there was a correlation between the role of the PARPAS with the knowledge and attitudes of high school students in Sidoarjo about HIV/AIDS prevention. However, there is no correlation between the role of PARPAS with the behavior of high school students in Sidoarjo about HIV/AIDS prevention.

\section{Suggestion}

Related to this problem it is advisable to hold early detection to high school students in Sidoarjo; invites students to play an active role in an organization so that students are not easily influenced by promiscuity that can plunge. Conduct counselling both for students and parents so they can supervise each other, and the counselling should be held regularly and invites students to get used to a healthy life.

\section{REFERENCES}

Ayuningsih, N., Rondonuwu, R., and Mulyadi, 2014. Pengaruh Penyuluhan tentang HIV/AIDS terhadap Pengetahuan dan Sikap Siswa di SMA Negeri 1 Manado. Jurnal Keperawatan, 2 (2), pp. 1-7.

Hamdi, A.C., Wijaya, M., and Iskandar, S., 2016. Pencegahan Penularan HIV/AIDS: Efektivitas Metode KIE "Aku Bangga Aku Tahu (ABAT)". Buletin Peneliti, 44 (4), pp. 245-252.

DOI: https://doi.org/10.22435/bpk.v44i4.5357.2 45-252.

Husaini, Panghiyangani,R., and Saputra, M., 2017. Pengaruh Penyuluhan HIV/AIDS terhadap Pengetahuan dan Sikap tentang HIV/AIDS Mahasiswi Akademi Kebidanan Banjarbaru Tahun 2016. Buletin Penelitian Kesehatan, 45 (1), pp. 11-16.

DOI: http://dx.doi.org/10.22435/bpk.v45i1.5787 .11-16.

Indonesian Ministry of Health, 2014. Infodatin: Situasi dan Analisis HIV/AIDS. Jakarta.

Isni, K., 2016. Dukungan Keluarga, Dukungan Petugas Kesehatan, dan Perilaku Ibu HIV dalam Pencegahan Penularan HIV/AIDS ke Bayi. Jurnal Kesehatan Masyarakat, 11 (2), pp. 96-104. DOI: https://doi.org/10.15294/pack.v11i2.4014.

Kusuma, A. A., 2010. Hubungan antara Pengetahuan, Sumber Informasi, dan 
Pemahaman Agama dengan Perilaku Mahasiswa terhadap HIV/AIDS. Thesis. Universitas Muhammadiyah Surakarta.

Ministry of Education and Culture, 2019. Data Pokok Pendidikan Dasar dan Menengah. Available at: http://dapo.dikdasmen.kemdikbud.go.id/sp /2/050200 (Accessed: September 14, 2019).

Natalia, Y. D., Sunanrti, N.T.S., and Astuti, I.R., 2014. Penyuluhan tentang HIV dan AIDS terhadap Sikap Remaja pada Orang dengan HIV dan AIDS. Jurnal Studi Pemuda, 3 (1), pp. 25-31. DOI: https://doi.org/10.22146/studipemudaugm. 32035 .

Nita, S., and Hari, B.N., 2016. Pengaruh Pengetahuan, Kontrol Diri terhadap Perilaku Seksual Pranikah di Kalangan Remaja SMK di Surabaya. Jurnal Biometrika dan Kependudukan, 5 (2), pp. 125- 134.

Notoatmodjo, S., 2010. Ilmu Perilaku
Kesehatan. Jakarta: Rineka Cipta.

Susanti, E., 2015. Pengaruh Penyuluhan terhadap Pengetahuan tentang Kesehatan Reproduksi Remaja Siswa Kelas VII di SMPN 14 Yogyakarta. Thesis. Sekolah Tinggi Ilmu Kesehatan 'Aisyiyah Yogyakarta.

Widarma, I. G. H., Hayati, S., and Maidartati. 2017. Pengaruh Penyuluhan Kesehatan terhadap Pengetahuan Remaja tentang HIV/AIDS di Kabupaten Bandung. Jurnal Keperawatan BSI, 5 (1), pp. 29-37.

Worinsi, A.N., 2017. Pengaruh Penyuluhan Pencegahan HIV/AIDS terhadap Tingkat Pengetahuan Remaja di SMA Ma'arif Kota Yogyakarta. Universitas 'Aisyiyah Yogyakarta.

Yuliza, W. T., Hardisman and Nursal, D.G.A., 2019. Analisis Faktor yang Berhubungan dengan Perilaku Pencegahan HIV/AIDS pada Wanita Pekerja Seksual di Kota Padang. Jurnal Kesehatan Andalas, 8 (2), pp. 376-384. 